\title{
PEMBERDAYAAN WARGA NEGARA DAN KEWIRAUSAHAAN SOSIAL: PEMUTUSAN MATA RANTAI ANAK JALANAN
}

\author{
Meidi Saputra \\ Jurusan Hukum dan Kewarganegaraan, Universitas Negeri Malang \\ Jl. Semarang No.5 Malang \\ email: meidi.saputra.fis@um.ac.id
}

\begin{abstract}
This study aims at describing the citizen empowerment through social entrepreneurship as an effort to break the chain of street children. The design of this research is a case study, with the street children in Semarang as the subject of research. The research finding shows that citizen empowerment through social entrepreneurship plays an important role in breaking the chain of street children. The creation of Dynamic Learning methodis an important instrument in breaking the chain of street children. Dynamic Learning as a practice of social entrepreneurship has played an important role in giving the impact of citizen empowerment so as to improve the economy and social classes of marginalized citizens.
\end{abstract}

Keywords: citizen empowerment, social entrepreneurship, street children, dynamic learning

\begin{abstract}
Abstrak:Tujuan penulisan adalah untuk mendeskripsikan pemberdayaan warga negara melalui kewirausahaan sosial sebagai upaya memutus mata rantai anak jalanan. Rancangan penelitian ini adalah studi kasus dengan subjek penelitian, yaitu anak-anak jalanan di Kota Semarang. Temuan penelitian menunjukkan bahwa pemberdayaan warga negara melalui kewirausahaan sosial memiliki peranan penting dalam memutus mata rantai anak jalanan. Penciptaan metode Pembelajaran Dinamis (Dynamic Learning) merupakan instrumen penting dalam memutus mata rantai anak jalanan. $D y$ namic Learning sebagai praktik kewirausahaan sosial telah berperan penting dalam memberikan dampak keberdayaan warga negara sehingga dapat meningkatkan perekonomian dan kelas sosial warga negara yang terpinggirkan.
\end{abstract}

Kata Kunci: pemberdayaan warga negara, kewirausahaan sosial, anak jalanan, dynamic learning

Indonesia adalah salah satu negara dengan penduduk terbesar di dunia. Dengan jumlah penduduk yang mencapai 261.890 .900 juta jiwa pada tahun 2017, Indonesia menempati posisi keempat dibawah Cina, India, dan Amerika. Jumlah ini akan terus meningkat setelah Bappenas merilis laporan Proyeksi Penduduk Indonesia 20102035. Dalam rilis tersebut, pada tahun 2020 diprediksi jumlah penduduk Indonesia menyentuh angka 271 juta jiwa atau lebih banyak 10 juta dari jumlah penduduk di tahun sebelumnya. Bahkan pada 2035, jumlah penduduk Indonesia diprediksi akan menyentuh angka 300 juta jiwa (Katadata, 2017).Jumlah penduduk yang banyak tentu saja melahirkan konsekuensi positif dan negatif. Dengan jumlah penduduk yang besar tentu saja hal ini menjadi bonus demografi untuk menyongsong generasi emas 2045. Akan tetapi bonus demografi ini akan menjadi beban bahkan bom waktu bagi negara apabila tidak diiringi dengan peningkatan kualitas hidup manusia didalamnya.

Salah satu isu penting peningkatan kualitas hidup manusia Indonesia adalah kesejahteraan. Kesejahteraan yang belum merata berdampak dengan kemiskinan yang dialami penduduk Indonesia. Dalam rilis data Badan Pusat Statistik per September 2017, penduduk miskin Indonesia mencapai 26,58 juta jiwa $(10,12 \%)$. Jumlah yang cukup tinggi jika dilihat dari jumlah total penduduk Indonesia yang hampir mencapai 262 juta jiwa (BPS, 2017). Kenyataan ini tentu saja membuat pemerintah harus terus bekerja keras agar angka kemiskinan dapat turun. 
Kompleksitas permasalah kemiskinan di Indonesia perlu diatasi. Dalam konstitusi negara UUD NRI 1945 Pasal 34 (1) berbunyi: "Fakir miskin dan anak-anak yang terlantar dipelihara oleh negara." Jika mengacu pada hal ini, tentu pemerintah sudah mempunyai tanggung jawab terhadap warga negara di dalamnya. Akan tetapi mengingat kompleksnya permasalahan kemiskinan, maka diperlukan suatu langkah inovatif dari warga negara untuk membantu pemerintah dalam mengentaskan kemiskinan. Salah satu cara untuk mengatasi hal tersebut adalah kewirausahaan sosial (social entrepreneurship).

Kewirausahaan sosial adalah sebuah aktivitas sosial yang menggunakan pendekatan inovatif dalam mengatasi permasalahan yang ada di masyarakat, dengan menitikberatkan pada ketercapaian nilai sosial dibandingkan mencari profit untuk keuntungan pribadi/lembaga (Emerson \& Twersky, 1996; Zadek dan Thake, 1997; Johnson, 2000; Dess and Anderson, 2003; Austin, et al., 2012). Kewirausahaan sosial telah memiliki peran penting dalam mengurai permasalahan sosial di masyarakat. Dikatakan demikian bahwa penciptaan nilai sosial yang dihasilkan oleh kewirausahaan sosial dengan menggunakan kemampuan entrepreneurship berperan besar dalam melakukan perubahan sosial (social change), terutama meliputi bidang kesejahteraan (welfare), pendidikan dan kesehatan (healthcare) (Hulgard, 2010; Cukier, 2011).Hadirnya lembaga-lembaga seperti Nahdlatul Ulama (NU), Muhammadiyyah, Aksi Cepat Tanggap (ACT) merupakan contoh riil di lapangan bagaimana kewirausahaan sosial bekerja dalam menghadirkan perubahan sosial.

Seiring dengan perkembangan ilmu pengetahuan, praktek kewirausaahan sosial dalam mengatasi kemiskinan telah bertransformasi menjadi pemberdayaanwarga negara. Pemberdayaan yang dimaksud adalah bagaimana warga negara memiliki kemandirian untuk berpartisipasi aktif dalam mengembangkan potensi yang ada pada diri atau lingkungannya. Pemberdayaan warga negara melalui kewirausaahan sosial ditemukan peneliti pada Kawasan Brintik, Kompleks Bergota, Kelurahan Randusari, Kota Semarang. Kawasan ini merupakan tempat tinggal anak-anak jalanan yang banyak mengamen dan mengemis di kawasan Tugu Muda Kota Semarang. Mereka melakukan aktivitas itu untuk membantu orangtua mereka yang kesulitan ekonomi.
Upaya untuk menanggulangi hal ini, tentu saja sudah mendapat perhatian dari pemerintah, dalam hal ini Dinas Sosial. Akan tetapi, perhatian tersebut hanya sebatas memberikan pelatihan tanpa memberikan pemberdayaan kepada masyarakat. Akibatnya, mau tidak mau anak-anak jalanan tadi kembali ke jalanan untuk mengemis dan mengamen bahkan terjadi regenerasi yang menular kepada adik-adik mereka. Kenyataan atas hal ini, membuat lahirlah organisasi nirlaba berbasis kewirausahaan sosial yang bernama Dynamic Learning di Semarang. Organisasi merupakan bentuk ikhitiar dalam memutus mata rantai anak jalanan dari aktivitas mengamen dan mengemis di jalanan.

Selaras dengan pemaparan di atas, tumbuh dan berkembangnya organisasi nirlaba bernamaDynamic Learning, perlu dimasukkan ke dalam kajian akademik kewirausahaan sosial. Komitmen mereka dalam praktik kewirausahaan sosial, dengan memberikan pendidikan dan pemberdayaan terhadap anak-anak jalanan perlu untuk diteliti. Harapannya hasil penelitian ini bisa dijadikan referensi dalam mencapai perubahan sosial di masyarakat utamanya memutus mata rantai anak jalanan.

\section{METODE}

Metode yang digunakan dalam penelitian ini adalah metode penelitian kualitatif dengan pendekatan deskriptif. Metode penelitian kualitatif merupakan metode yang melibatkan pendekatan interpretatifdan pendekatan yang beralasan atas tiap-tiap subyek yang diteliti. Pendekatan ini berusaha untuk mengeksplorasi dan memberikan pemaknaan atas permasalahan atau fenomena sosial berdasarkan fakta yang ditemukan di lapangan (Neuman, 2007; Creswell, 2017). Teknik pengumpulan data yang dilakukan dalam penelitian ini adalah observasi dan wawancara mendalam. Sementara teknik yang digunkana dalam menentukan informan adalah purposive sampling. Adapun informan yang diwawancarai secara mendalam adalah pendiri $D y$ namic Learning, pengurus Dynamic Learning, anak-anak jalanan, ibu dari anak-anak jalanan dan masyarakat sekitar Kawasan Brintik Kelurahan Randusari Kota Semarang.

\section{HASIL DAN PEMBAHASAN}

Dewasa ini kehidupan warga negarasemakin hari semakin berkembang dan maju. Kehidupan 
warga negara yang telah memasuki revolusi industri ke 4.0 tentu saja membawa keuntungan bagi warga negara. Akan tetapi, hal ini membawa sebuah konsekuensi dimana kehidupan warga negara saat ini terkena dampak dari world interlinkages. Bukti nyata dari hal ini adalah berupa permasalahan sosial yang semakin hari semakin kompleks bahkan cenderung mengarah ke chaostic (Saputra, 2017). Kehidupan terus berjalan, maka warga negara pun harus bertahan dengan keadaan demikian. Di saat inilah warga negara dituntut untuk mempertahankan kehidupannya sehingga berbagai cara pun dilakukan. Salah satu permasalahan sosial akibat dampak dari world interlinkages ini adalah kemiskinan.

Kemiskinan merupakan permasalahan sosial yang memerlukan penanganan yang serius. Angka kemiskinan yang mencapai 26,82 juta jiwa pada warga negara Indonesia jelas tentu saja tidak bisa dibiarkan begitu saja. Kondisi demikian membuat warga negara akan melakukan berbagai cara agar dapat memenuhi kebutuhan hidup sehari-hari. Bahkan tidak jarang pemenuhan kehidupan seharihari tersebut juga melibatkan anak-anak usia sekolah untuk membantu penghasilan keluarga lebih banyak dengan menjadikan mereka anak jalanan seperti yang ditemukan peneliti dalam tulisan ini.

Berdasarkan pemaparan diatas, maka pengentasan kemiskinan pada warga negara Indonesia memerlukan langkah inovatif agar warga negara lebih berdaya, mandiri dan bertanggungjawab dalam pemenuhan kebutuhan hidupnya.

\section{Kewirausahaan Sosial sebagai Inovasi dalam Meningkatkan Kelas Sosial Warga Negara}

Anak-anak di kawasan Brintik Kota Semarang tinggal di lingkungan yang tidak menguntungkan. Usia mereka yang seharusnya belajar di sekolah, bermain dengan teman sebaya, memperoleh penghidupan yang layak dari orang tua hanya menjadi angan yang bisa mereka pendam dalam-dalam. Kehidupan marginal tampak akrab dengan keseharian mereka. Mereka harus bekerja keras membantu orang tua mereka agar ekonomi keluarga dapat terus membaik. Akan tetapi, jalan yang ditempuh tersebut tidak ideal untuk mereka. Mereka dipaksa harus turun ke jalan dengan mengamen dan mengemis agar memperoleh uang. Tentu kondisi demikian tidak ideal untuk generasi penerus yang harusnya hak-hak mereka terpenuhi.
Kemiskinan jelas menjadi faktor utama kenapa anak-anak Kawasan Brintik Kota Semarang melakukan hal demikian. Kemiskinan memang telah menjadi permasalahan sejak lama. Zaman yang terus menerus berkembang membuat kehidupan warga negara terdisrupsi termasuk juga penanganan kemiskinan yang melibatkan anak jalanan. Dibutuhkan cara-cara baru yang dapat mendobrak cara-cara lama yang terkesan rigid, $\mathrm{kaku}$, tidak berkelanjutan dalam penanganan kemiskinan sehingga tidak memperparah keadaan itu sendiri. Penangananan kasus kemiskinan memerlukan inovasi yang harus mampu membuat kaum-kaum marjinal menjadi lebih berdaya dan berkeadilan tanpa harus menunggu bantuan pemerintah.

Salah satu langkah mengatasi hal tersebut adalah kewirausahaan sosial.Kewirausahaan sosial merupakan suatu langkah inovatif dan solutif dalam membantu pemerintah mengatasi kemiskinan sebagai permasalahan sosial. Penanganan permasalahan sosial pada warga negara jelas membutuhkan lebih dari sekedar intervensi pemerintah dan untuk itulah kewirausahaan sosial dipilih (Dhewanto, 2013). Sifat kewirausahaan sosial yang lebih mementingkan nilai sosial dibandingkan keuntungan diyakini semakin membuat kewirausahaan sosial dipilih sebagai jalan memberdayakan warga negara.

Usaha penanganan kemiskinan yang melibatkan anak jalanan di Kawasan brintik, Kota Semarang telah membuat sekelompok anak-anak muda di Kota Semarang mendirikan organisasi Nirlaba yang bernama Dynamic Learning Indonesia. Organisasi yang bercikal bakal dari program kreativitas mahasiswa dan komunitas mengajar ini didirikan sebagai bentuk ikhtiar memutus mata rantai anak jalanan yang berbasis kewirausahaan sosial. Berawal dari keprihatinan para anggota yang menemukan anak-anak jalanan yang mengamen dan mengemis di jalanan, telah menginisiasi Dewi Nur Cahyaningsih (Pendiri Dynamic Learning) untuk memutus rantai anak jalanan di Kota Semarang. Kenapa dikatakan memutus mata rantai anak jalanan? Sebab anak-anak jalanan yang mengamen dan mengemis ternyata beregenerasi dalam keluarga. Tentu saja pengaruh dari orang tua mereka sebagai pemeran utama yang menyuruh mereka mencari nafkah di jalanan.

Dengan melihat fakta demikian, maka dibutuhkan suatu metode yang dapat 
mengakomodir persoalan tersebut dengan kegiatan yang positif, sekaligus memutus mata rantai eksploitasi anak-anak dan mengentaskan mereka dari kehidupan di jalanan. Setelah melalui serangkaian proses menemukan ide-ide kreatif, maka ditemukanlah metode pembelajaran khas social entrepreneurship dalam rangka menaikkan kelas sosial warga negara yang terpinggirkan. Metode itu adalah Dynamic Learning.

\section{Dynamic Learning sebagai Integrasi Orang Tua dan Anak dalam Pemutusan Mata Rantai Anak Jalanan}

Usaha untuk memutus mata rantai anak jalanan dari eksploitasi orang tua tentu saja bukanlah hal yang mudah. Kebiasaan selama ini di jalanan yang menghasilkan uang, harus diganti dengan kegiatan pendidikan dan pemberdayaan tentu sedikit banyak memerlukan adaptasi dari anak-anak jalanan di Kawasan Brintik, Kota Semarang. Belum lagi orang tua dari anak-anak yang terkesan menyepelekan bahkan cenderung tidak bersahabat. Alasan para orang tua ini sebenarnya sederhana. Mereka beranggapan kegiatan yang sering mereka terima selama ini hanya sekedar formalitas, tidak berkelanjutan dan tidak menghasilkan apa-apa. Dalam kondisi demikian, lahirlah organisasi nirlaba berbasis kewirausahaan sosial di Semarang yang bernama Dynamic Learning. Dynamic Learning didirikan atas prakarsa Dewi Nur Cahyaningsih, seorang aktivis sosial pecinta anak-anak. Kecintaannya pada anak-anak dan ingin menyelamatkan generasi muda dari eksploitasi orang tua, dibuktikannya dengan menelurkan ide kreratif untuk mendirikan Dynamic Learning.

Dynamic Learning adalah sebuah startup kewirausahaan sosial berbasis pendidikan karakter dengan mengedepankan lima pilar utama yakni keimanan, nasionalisme, teknologi, motivasi, dan kewirausahaan. Didirikan Dynamic Learningbertujuan untuk meningkatkan perekonomian dan kelas sosial warga negara yang

\section{DAFTAR RUJUKAN}

Austin, J., Stevenson, H., \& Wei-Skillern, J. 2012. Social and commercial entrepreneurship: same, different, or both? Revista de Administração. terpinggirkan dengan memberdayakan ibu dan anak jalanan, anak putus sekolah, serta mantan penyalahguna narkoba. Fokus utama Dynamic Learning adalah pendidikan dan pemberdayaan. Pertama, pendidikan yang menekankan pada society character untuk anak-anak. Kedua, pemberdayaan berupa pelatihan e-commerce untuk orang tua. Kedua hal ini merupakan integrasi aktivitas orang tua dan anak, dengan harapan dapatmeningkatkan kesejahteraan masyarakat dan kualitas hidup mereka. Anak-anak dikembalikan pada "fitrah" mereka yakni belajar dan bermain, sementara orang tua mereka diberikan motivasi, pendampingan, pelatihan sekaligus penjualan dari hasil karya mereka sehingga ekonomi mereka kian membaik.

\section{SIMPULAN}

1. Kompleksnya permasalahan kemiskinan diperlukan suatu langkah inovatif dari warga negara untuk membantu pemerintah dalam mengentaskan kemiskinan. Salah satu langkah mengatasi hal tersebut adalah kewirausahaan sosial.Sifat kewirausahaan sosial yang lebih mementingkan nilai sosial dibandingkan keuntungan diyakini semakin membuat kewirausahaan sosial dipilih sebagai jalan memberdayakan warga negara.

2. Pemberdayaan warga negara melalui kewirausahaan sosial memiliki peranan penting dalam memutus mata rantai anak jalanan. Penciptaan metode Pembelajaran Dinamis (Dynamic Learning) yang diintegrasikan dengan kegiatan orang tua dan anak merupakan instrumen penting dalam memutus mata rantai anak jalanan. Dengan dua focus utama yakni pendidikan pada anak jalanan berbasis society character dan pemberdayaan pada orang tua berbasis e-commerce, harapannya dapat memberikan dampak keberdayaan warga negara sehingga dapat meningkatkan perekonomian dan kelas sosial warga negara yang terpinggirkan.

Badan. Pusat Statistik. 2018.https:// www.bps.go.id/website/images/BRSKEMISKINAN-JAN-2018-ind.jpg (Diakses tgl 14 juli 2018) 
Creswell, J. W., \& Creswell, J. D.2017. Research design: Qualitative, quantitative, and mixed methods approaches. Sage publications.

Cukier, W., Trenholm, S., Carl, D., \& Gekas, G. 2011. Social entrepreneurship: a content analysis. Journal of Strategic Innovation and Sustainability.

Dhewanto, W. 2013. Inovasi dan Kewirausahaan Sosial. Alfabeta. Bandung.

Dees, J. G., \& Anderson, B. B. (2003). For-profit social ventures. International Journal of Entrepreneurship Education, 2(1).

Emerson, J., \& Twersky, F. (Eds.). (1996). New social entrepreneurs: The success, challenge and lessons of non-profit enterprise creation. The Homeless Economic Fund, the Roberts Foundation.

Hulgård, L. 2010. Discourses of social entrepreneurship-Variations of the same theme. EMES European Research Network.

Katadata. 2018.https://databoks.katadata.co.id/ datapublish/2018/01/12/berapa-jumlahpenduduk-indonesia (Diakses tgl $13 \mathrm{Juli}$ 2018).

Johnson, S. 2000. Literature review on social entrepreneurship. Canadian Centre for Social Entrepreneurship.

Neuman, W. L., \& Robson, K. 2007. Basics of social research: Qualitative and quantitative approaches. Power.

Saputra, M. 2017. Pembinaan Kesadaran Lingkungan Melalui Habituasi Berbasis Media Sosial Guna Menumbuhkan Kebajikan Moral Terhadap Pelestarian Lingkungan. Jurnal Moral Kemasyarakatan, Volume 2Nomor 1.

Zadek, S., \& Thake, S. 1997. Send in the social entrepreneurs. New Statesman, 126(458). 